\title{
Global Justice: Building International and Supranational Structures on the Basis of Fundamental Rights
}

\author{
Edgar Lammertse* \\ Senior Coordinating Legal and Policy Advisor and Lawmaker \\ at the Ministry of Education, Culture, and Science of the Netherlands
}

\begin{abstract}
This article is intended to share a few thoughts, notions and questions about regulatory and governmental structures, both national and international, with regard to the development of global justice. It will highlight the issue whether or not local wisdom can contribute to global justice. In addition, this writing will discover legal problems that arise from the idea of global society and global justice by analyzing jurisdictional aspects and by explaining a little bit about dematerialization of crime, as it has been affected by the changing of communities behavior in global contexts after the era of computer and information and communication technology (ICT). Progressive development in Europe, especially regarding the European Union Law, will also be explored in order to describe the respect for fundamental rights in this region.
\end{abstract}

Keywords: Global Justice, International Society, Development, Local Wisdom.

\section{INTRODUCTION}

It is important to recognize that the increase of interdependency between nations and citizens in modern global society urges to build new legislative structures that go beyond local, regional and national sovereignty. It is also to be noticed that, unlike the Asian, Arabian or African world, in Western Europe, local tribes and communities with their own history, culture, social and legal systems never existed or lasted long enough to play a dominant role in shaping or changing structures of governmental and legal regimes. ${ }^{1}$ In fact these local tribes and communities were easily "eaten up" by bigger powers, for example the Roman Empire, the Franks, and the Teutons. The present governmental and legal structures in Western Europe are still partly designed on the basis of or derived from the structures these big powers brought in. For instance, a major part of Western European legal systems, especially in the field of civil law and criminal law, can be directly related back to the French legal systems and governmental structures of the French period at the end of the eighteenth and the beginning of the nineteenth century.

\footnotetext{
* Correspondence: 1.g.lammertse@minocw.n1

${ }^{1}$ See how local laws, customs, and Roman law had ever played in legal practice in Europe in Tammo Wallinga, "The Common History of European Legal Scholarship,"Erasmus Law Review 4, Issue 1 (2011): 3. http://www.erasmuslawreview.nl/tijdschrift/ELR/2011/1/ELR_2210-2671_2011_004_001_002.pdf It is interesting to take note that, however, local law may be taken into account (Ius Romano-Germanicum and Roman law) to be applied to cases of local importance. See Martin Otto, Law (European History Online,2011), http://ieg-ego.eu/en/threads/backgrounds/law See also Friedeburg, Robert von State Forms and State Systems in Modern Europe, European History Online, http://ieg-ego.eu/en/threads/crossroads/politicalspaces/robert-von-friedeburg-state-forms-and-state-systems-in-modern-europe/at_download/dnb.
} 
For centuries Western Europe was sparsely populated, without much social and cultural tradition, economic activities and trade, and without mature administrative and governmental structures. This more or less forgotten swampy area was an easy prey for invading powers, due to desintegration and the lack of coherent structures. As far as there were local communities with specific traditions, structures and believes, they could not stand up or maintain their position against the often violent and ruthless occupiers. Western Europe is relatively flat, except for the mountainous areas: The Alps and Pyrenees. People could travel quite easily and invaders were not hindered by too difficult geographic obstacles. This situation entails that there was no chance for local communities to survive the dominance of greater powers, however, it should be noted that this does not mean that there was no social-cultural diversity in Europe. On the contrary, this may form one of the social, demographic and geological explanations $^{2}$ behind the fact that in Western-Europe the creation of international and supranational economic and legal structures are relatively "easily" established.

This situation differs from the situation in other parts of the world, especially the East. Throughout millennia this part of the world has experienced the development of many civilizations and is still rich of indigenous social and cultural groups. Indeed, geographic conditions play a key role in the development of social, cultural, governmental and legal structure of countries.

The geographic conditions in some parts of Asia are very different. Inhospitable mountainous areas and many isolated islands enabled local communities to develop and maintain their own specific traditions, beliefs and regulatory systems,even without any connection to other social groups and communities. Unlike in Western Europe, the traditions, religions and wisdom of the indigenous groups in the East still have enormous influence on all day life, morality, social positions, behavior, legal positions and regulatory systems. Therefore it raises the question if and how this local wisdom can be recognized, described, reached, validated, judged, connected with and incorporated in the present global governmental and legislative structures.

\section{THE PURPOSE OF ARTICLE}

This article is intended to share a few thoughts, notions and questions about regulatory and governmental structures, both national and international, with regard to the development of global justice and seen from the - perhaps limited scope of a governmental employee in a small country in Western Europe, the Netherlands. These thoughts, notions and questions not only emerge from the author's experiences as a law maker, but also from personal interests and experiences. It will

${ }^{2}$ Analysis on ecodemographic dimension of human collectivities may be read in John Gerard Ruggie,"Territoriality and Beyond: Problematizing Modernity in International Relations," International Organization 47, No. 1 (Winter, 1993): 152-154, http://www.rochelleterman.com/ir/sites/default/files/Ruggie\%201993.pdf. 
address some issues that arise from the question whether local traditions, insights and wisdoms should influence legislative and governmental structures and can contribute to global justice and will also provide a short introduction to global and European legal systems. The following description will be outlined as follow. First, this writing will highlight the issue whether or not local wisdom can contribute to global justice. Second, it will discover legal problems that arise from the idea of global society and global justice by analyzing jurisdictional aspects and by explaining a little bit about dematerialization of crime, as it has been affected by the changing of communities' behavior in global contexts after the era of computer and ICT. Lastly, a conclusion will sum up the analysis of this article.

\section{CAN LOCAL WISDOM CONTRIBUTE TO GLOBAL JUSTICE?}

It is undeniable that everybody is willing to recognize and respect the old traditions and wisdoms of traditional local communities and indigenous groups and value their contribution to the variety of the human race as the basis on which we are able to build the world of today. I remember the images taken in 2011 from a plane, showing a primitive tribe in the dense rainforests at the border of Peru in South America, which existence was unknown until then. It is estimated that there are still a few dozens of these indigenous tribes, living isolated from the outside world. ${ }^{3}$ When I saw the pictures I tried to connect what I saw with our modern world. And I realized that when we observe these traditional people we are looking back in time. Like watching the stars, knowing that the light was emitted a long time ago and that the particular star you are staring at probably already extinguished. In the meantime the universe and the world have changed. Today we send outer-space probes on far away missions into the universe. We study ancient stars, distant galaxy's and planets, black holes and other mysterious phenomenon's of the universe, hoping to find facts and explanations that can reveal and explain our presence on planet earth and our place in the universe. Today we live in a worldwide community, using high-tech communication systems and modern techniques to travel all around the world and beyond. We do not live anymore in hidden and unexplored places, with ancient traditions and beliefs, but in a global village, trying to live together in peace, harmony and prosperity on the basis of commonly accepted principles of human rights and human dignity. The world changes undeniable and unstoppable. And it changes fast.

We study nature and ancient civilizations to learn about the meaning of human life, our behaviour and our thoughts and to know where we come from. Knowledge gives us insight in how we think, act and believe today and helps us to make progress in building a better world. That in my opinion is the meaning and purpose

${ }^{3}$ See Survival International, "The Uncontacted Indians of Brazil," http:/ /www.survivalinternational. org/tribes/uncontacted-brazil andinformation provided in http://www.funai.gov.br/. 
of studying the traditions of ancient civilizations and still existing local communities and indigenous people. But this is not yet followed by the logical conclusion that all the old wisdoms owned by these local communities and indigenous people are suitable to be incorporated in today's modern legal systems.

It is interesting to cite the speech of the former United States President Barack Obama on 26th July 2015 when he visited Kenya, the country where he was born. ${ }^{4}$ Besides speaking with respect about the people of Kenya and their culture and traditions, he also addressed the problems and challenges the country is facing by mentioning some local traditions, for instance the old habit of genital mutilating of young girls and the bad treatment of girls and women as second-class citizens. ${ }^{5} \mathrm{He}$ strongly pleaded for abolishing these traditions, arguing that they do not fit in the twenty-first century and our modern views on the rights of every human being. In other words, such local traditions do not contribute to equality, social and economic progress, peace and justice. Former President Obama hereby referred to the new Kenyan Constitution, where it is stated that "every person has inherent dignity and the right to have that dignity respected and protected." 6 The former President put the finger on the sore spot by saying that just because something is a tradition or part of our past does not make it right. We should understand our history, but we have to recognize that it also sends bad messages to those who suffered from bad treatment or injustice.

Rather than on preserving traditions, the focus of life in modern times lies on and efforts are directed towards economic growth, prosperity, education, eradication of the great misbalance between rich and poor, the combat against diseases and preserving nature. These elements, alongside the recognition of the principle of human dignity and the essential human rights for every person, are of great importance in achieving worldwide harmony, justice and peace.

This raises the question whether we should try by all means to preserve local communities and indigenous people just for the sake of preventing them from extinguishing. Certainly, we treasure the existence of indigenous people and traditional communities. We also recognize the right of these people to maintain their traditional way of living. That is why we make efforts to protect and preserve them, on a national and international scale by binding regulations, declarations and treaties. ${ }^{7}$ But with our modern techniques we are able to explore and cultivate every inch of

\footnotetext{
${ }^{4}$ https://www.whitehouse.gov/the-press-office/2015/07/26/remarks-president-obama-kenyanpeople.

5 An interesting analysis regarding this issue may be read in Geofrey Towett, Peter GutwaOino, and Audrey Matere, “The Female Genital Mutilation Act 2011 of Kenya: Challenges Facing its Implementation in Kajiado

${ }^{6}$ Constitution of Kenya, Art.28. National Council for Law Reporting with the Authority of theAttorney General, Laws of Kenya: Constitution of Kenya,The Official Law Reports of the Republic of Kenya, Revised Edition 2010.

7 See for instance the United Nations Declaration on the Rights of Indigenous Peoples, adopted by the General Assembly of the United Nations on September 17th 2007,61/295.
} 
our planet. Sooner or later modern society will penetrate into the life of indigenous people and their communities and affect their way of living. From that moment on they are caught up in the slipstream of modern society. The question is how long the traditions will last. Are young people, who taste the temptations of earning money, modern life and possessing economic goods, still willing to learn and maintain the old traditions and wisdoms of their community and ancestors and transfer them to next generations? Or will they choose for education and jobs in the hunt for the luxury of the modern life? We can and must try to preserve traditions. But sooner or later and with all respect, they become more and more items like art pieces in a global museum. We can study them, but the basic question is whether we can use them as the binding regulator and guidance for global society and global justice. Local traditions and wisdoms are more and more becoming sanctuaries for those who seek personal enrichment and inner peace.

Thinking about incorporating the local, traditional philosophies as well as wisdom in legal systems that are binding, places us in front of some challenges. The first one is to obtain consensus about the idea of incorporating local wisdom in regulatory systems. We can have discussion about this, because the world today is asking for new and modern concepts of basic principles and structures on which global legal systems have to be built in order to create a safe and harmonious world. The incorporation of local wisdoms and philosophies that are traditional and typical for a limited group in legally binding systems conflicts with the idea that global justice requires the adoption of commonly accepted principles. The second challenge is to determine the criteria to validate and judge local wisdoms for their appropriateness with regard to global justice. It is a very difficult task. It should be clear that there is no traditional wisdom that can be accepted for incorporation in legislative systems that conflicts with human dignity and human rights, that discriminates, or that has violent propaganda elements. ${ }^{8}$ For instance, the caste-system according to which people are divided in groups with different legal rights and social and economic opportunities is only on the basis of descent or origin, the more fundamentalist visions with violent elements of corporal punishment, and the denying of women's rights.

To me such "wisdoms", although they may be traditional and ancient, can never contribute to any form of global justice in our modern world. And I want to add something more. We have to learn from the past, we have to learn from the wisdoms, traditions, religions, achievements and mistakes of our ancestors and all kinds of traditional communities. But today, human dignity, reason, economics, progress and science are our guidelines for building legal systems for the benefit of all individuals on earth. Policy making and law making in modern society are evidence

\footnotetext{
${ }^{8}$ In respect of preserving the rights of indigenous people, the UN Declaration on the Rights of Indigenous Peoples states in Article 34 that indigenous peoples have the right to promote, develop and maintain their institutional structures and their distinctive customs, spirituality, traditions, procedures, practices and, in the cases where they exist, juridical systems or customs, in accordance with international human rights standards.
} 
based and the legal rights and obligations of people should be as much as possible determined by objective criteria and at least commonly accepted principles. Otherwise we turn into a legal system that Bertrand Russel (1872-1970) characterized as "wherein law in origin is merely a codification of the power of dominant groups, and does not aim at anything that to a modern man would appear to be justice." And I again refer to the Kenya-speech of former President Obama, when he said that a politics that is based solely on tribe and ethnicity is a politics that is doomed to tear a country apart. ${ }^{10}$

\section{LEGAL PROBLEMS THAT ARISE FROM THE IDEA OF GLOBAL SOCIETY AND GLOBAL JUSTICE}

Due to modern information and communications techniques, enormous social and economic changes are going on today. The development of what we call "the Information Society" offers unique and unforeseen chances for worldwide social and economic activity and prosperity. But the development of the Information Society has also its drawback. A lot of questions and problems arise with regard to security, crime, privacy, morality and health. Opinions differ a lot whether the development of the Information Society is a blessing to the world, or a blessing in disguise.

In this part of this article I would like to jump into modern times and address some legal issues that arise simultaneously with the development towards a modern global Information Society. The first issue is jurisdiction. The second issue is the changing character of crimes. Although they are of a different nature, these issues play a key role in thinking towards the establishment of global legal systems and global justice. Globalization and internationalization ask for standardization (techniques, measures, language, terms of education) and regulation. For instance, if we do not speak the same language and do not understand each other in the field of technical specifications needed for manufacturing Information and Communication Technology (ICT) systems, outer-space crafts, air planes, and communication systems, we will never be able to communicate with each other and, consequently, disaster will occur. The modern techniques and communication systems provide not only an environment for new versions of existing crimes like theft, shake-down and blackmailing, but also the occurrence of new crimes related to ICT that can endanger and jeopardize the peaceful co-existence of people and communities. ${ }^{11}$ And we

9 B. Russell, Bertrand Russell's Best (New York: Routledge Classics, 2009), 117 people.

10 https://www.whitehouse.gov/the-press-office/2015/07/26/remarks-president-obama-kenyan-

11 See for example University Twente News, "ICT Plays an Increasing Part in Criminal Activities:Perpetrators are often Young, Female, and Dutch,"https://www.utwente.nl/en/ news/!/2013/3/158372/ict-plays-an-increasing-part-in-criminal-activities See also United Nations Office on Drugs and Crime, "Study on the Effects of New Information Technologies on the Abuse and Exploitation of Children, Vienna-New York,"https://www.unodc.org/documents/organized-crime/cybercrime/Study_ on_the_Effects.pdf. 
have to be aware that modern communication techniques offer new opportunitiesfor radical and terrorist groups to disseminate their propaganda and plant their violent ideas in the minds of people throughout the world. In order to address these issues properly, global understanding and cooperation are needed.

\subsection{Jurisdiction}

In the modern global Information Society where borders disappears, jurisdiction is one of the problematic issues. Communication, services and information go in a split second beyond national borders. The scale of activity has become worldwide. And that does not fit any longer in the way states organize their governmental and legal structures, which are based on territorial sovereignty. It is often difficult to determine where for example a crime is committed and which State has jurisdiction.

We are still far away from consensus about establishing a global legal system for addressing transnational legal cases. The sovereignty of States is a big obstacle towards the development of global legal systems that preside over and overrule individual states. A complication behind this is the fact that visions about what is allowed or not, for instance in the light of freedom of expression, ${ }^{12}$ freedom of speech and freedom of religion, differ throughout the world. There is no consensus and the way in which these visions are converted in constitutional legal provisions and legal systems depends on to the political, social, cultural and religious traditions and morality of individual sovereign states.

But it is not impossible to create global legal systems. The international community was successfully able to establish the International Court of Justice (ICJ) and the International Criminal Court (ICC), both residing in The Hague in the Netherlands. ${ }^{13}$ The ICJ is a principal judicial organ of the United Nations. ${ }^{14}$ It has

12 International Covenant on Civil and Political Rights, Art. 19.

13 The International Court of Justice (ICJ) first appeared on April 18th 1946 after its predecessor, The Permanent Court of International Justice, was abrogated. The International Court of Justice has its legal basis in the UN-Charter, but it has its own Statute. The International Criminal Court (ICC) was established on the initiative of the United Nations by the Rome Statute of the International Criminal Court in 1998 and was started effectively in 2002. Up to now, some 124 countries have become State Parties to the Statute. https://asp.icc-cpi.int/en_menus/asp/states\%20parties/pages/the\%20states\%20parties $\% 20$ to $\% 20$ the $\% 20$ rome $\% 20$ statute.aspx. These two courts are not the only ones with a global jurisdiction. In 1994 the International Tribunal for the Law of the Sea, ITLOS, was established. After World War II special ad-hoc tribunals were established on the basis of international agreements: the Nurenberg Tribunal and the Tokyo Tribunal. In 90s, special tribunals were established by the Security Council of the UN: in 1993 International Criminal Tribunal for the former Republic of Yugoslavia (ICTY) and in 1994 the International Criminal Tribunal for Rwanda (ICTR). The reason that these two tribunals were established under the powers of the Security Council, derived from Article VII of the UN-Charter, was that the Security Council considered the situation in both cases as a threat for international peace and security and that the establishment of the tribunals contributed to the restoration of peace in both regions. The attempt to establish a tribunal under the auspices of the Security Council was in July 2015 for the prosecution of those who are responsible for shooting down flight MH17 of Malaysia Airlines above Ukraine in July 2014. This attempt failed because of a Russian veto.

14 The Charter of the United Nations, Art. 7 (1). 
competence to settle cases involving States regarding public international law issues ${ }^{15}$ and to give a so called advisory opinion. ${ }^{16}$ Contrary to the ICJ that has mandate to proceed legal maters between States, the ICC solves the problem of jurisdiction in prosecuting genocide, crimes against humanity, war crimes and the crime of aggression. ${ }^{17}$ Although the establishment and legal powers of the ICC depend on the subscription of individual sovereign states that ratified the Rome Statute, the ICC can exercise its jurisdiction in a case that is brought before the court on the own initiative of the UN Security Council or the initiative of the prosecutor. ${ }^{18}$

On a global scale, there is still no such thing as a supranational system, in which states delegate some of their sovereignty to supranational governmental bodies. Such supranational legal systems exist only on a regional scale. The good example is the European Union (EU), particularly its economic pillars. The process of building the EU started in 1957 with the establishment of the European Coal and Steel Community (ECSC). ${ }^{19}$ The idea of creating a European community was a reaction after decades of very bloody wars, culminating in the horrific World War II. ${ }^{20}$ It was the start of uniting European countries in order to secure long lasting peace, economic growth, employment and stability. It was then understood that peace is not reached by political cooperation only, but also that economic cooperation and the recognition of essential human rights is conditio sine qua non to establish a situation where neighbouring countries can exist together in harmony. Beginning with putting the production of coal and steel - the former two pillars of war industries - under supranational supervision, the EU now has extended its supranational powers to many fields, including food/agriculture production, ${ }^{21}$ free flow of people and goods by abolishing protectionism, encouraging the creation of jobs, supporting poorer areas, preserving nature and issues concerning security and defense. ${ }^{22}$

\footnotetext{
15 The Statute of the International Court of Justice, Arts. 34 (1) and 36.

16 Ibid, Art. 65

17 The Rome Statute of the International Criminal Court and Resolution, Art.5. RC/Res.6,http:// www.icc-cpi.int/iccdocs/asp_docs/Resolutions/RC-Res.6-ENG.pdf.

18 Ibid, Art. 13.

19 Treaty of Paris, 1951, establishing the European Coal and Steel Community (ECSC).

${ }^{20}$ Preamble of the Treaty on the European Union, Consolidated version of the Treaty on European Union and the Treaty on the Functioning of the European Union, Official Journal C 326 , 26/10/2012 P. $0001-0390$

21 Treaty of Rome, 1967. By this treaty the European Economic Community (EEC) was established. The EEC was a merger of the European Coal and Steel Community (ECSC), the European Economic Community established in 1957 and the European Atomic Energy Community, also established in 1957. Although the Treaty of Rome expanded the powers of the EEC to more economic sectors, most important were an agriculture subsidizing system and a toll free region.

22 Treaties of Maastricht (1992) and Amsterdam (1997). The Treaty of Maastricht turned the EEC into the European Community (EC) and formed the basis for the Economic and Monetary Union (EMU) and prepared the introduction of a common currency, the euro $(€)$. In 2001 the Treaty of Nice was signed. Rather than expanding the powers of the EC this treaty mainly dealt with reforming the internal structures. In 2007 the Treaty of Lisbon was signed. By this treaty the European Community was transformed into European Union (EU). The treaty mentions climate change and energy issues as focus areas without extending the powers of the EU. The treaty also changed internal procedures and introduced a procedure for the exit of member states.
} 
In 1985 the Schengen Agreement was signed by France, Germany, Belgium, Luxembourg and The Netherlands, establishing the so called "Schengen-area" where internal borders were abolished to guarantee free flow of people and easy traffic of goods. The Schengen Agreement also aims at cooperation in the field of police services and judicial authorities. This agreement is now becoming part of the legal framework of the EU. The Schengen area has expanded to almost all member states of the EU, and is regarded as one of the most ambitious realizations of the EU. ${ }^{23}$ Within the borders of the Schengen area, people can travel freely without being checked and common rules apply for visa and asylum. The recent case of refugees, mainly from Syria, who try to enter the Western European countries has raised an issue about the effectiveness of the Schengen Agreement for its Parties.

The character of the EU as a supranational governmental body is shown in its binding legislative powers. For example, EU can create regulations as binding legislative act that must be applied in its entirety across the EU. Besides, EU may also impose directives, decisions, reccommendations, and opinions that have lower binding power compared to regulations. Secondly, the EU is a real political and governmental institution that can act on its own initiative. The European Commission as executive power and the European Court of Justice as judicial power can supervise the compliance by member states with the EU-legislation and can impose severe sanctions.

The most recent step towards further integration of the economies of the member states is the establishment of the Economic and Monetary Union (EMU). The EMU aims at the coordination and harmonization of economic, monetary and fiscal policy and the introduction of a common currency (the euro). ${ }^{24}$ Majority of EUmember states are involved in the EMU and the purpose is that in the end all EUmember states fulfil the criteria for adopting the euro. Most of EU members have adopted the euro as currency. ${ }^{25}$ It is to be noticed that the EMU is seen as an irreversible project. Member states cannot step out and no procedure is foreseen for pushing a member state out. To what consequences this can lead shows the recent case of Greece. Greece balances on the edge of bankruptcy and the leftwing administration refused to fulfil the conditions and arrangements set out by the monetary institutions and European leaders. Although an exit procedure is debatable, ${ }^{26}$ at some point a "grexit" - the exit of Greece out of the EMU - seemed

23 Anna Kiefer, "The Thirtieth Anniversary of the Schengen Agreement: Retrospective and Perspective in Light of the Migrant Crisis" (Cornell Int'l L.J. Online, (2015) Vol. 3: 25. http://cornellilj.org/wp-content/ uploads/2015/12/Anna-Kiefer-The-Thirtieth-Anniversary-of-the-Schengen-Agreement-3-CILJO-22.pdf

24 See description on monetary union in Klaus-Dieter Borchardt, The ABC of European Union Law (Luxembourg: Publications Office of the European Union, 2010), 20, 34, 54, 73, 74, 96.

25 The United Kingdom, Denmark, and Sweden have special treaty-based position. They are allowed to maintain their own currency. See Seth Shobhith, Why These European Countries Don't Use The Euro, (Investopedia,2016). http://www.investopedia.com/articles/investing/050515/why-these-european-countries-dont-use-euro.asp

26 See analysis by Jens C.Damman, "The Right to Leave the Eurozone,"Texas International Law Journal,48:125, Issue 2 (2013): 126-137. http://www.tilj.org/content/journal/48/num2/Dammann125.pdf. 
to be the only way out of the trouble in order to maintain the position of the euro and with that the economic stability of the European market. In last resort and after months of negotiations a "grexit" was averted. There is a lot of debate going on whether the Greece-case demonstrates the weakness of such supranational systems, or evidences the working of the system and the need for keeping everybody on board for the higher purpose of the prosperity of the European people. The shocking 'brexit'-the exit of United Kingdom (UK) out of the EU- also raises concern about the ability of the EU to maintain its supranational character. It cannot be denied that the UK is one of the big players in the EU, and a brexit will definitely have impact on the EU system. ${ }^{27}$

The supranational character of the EU-system means that cooperation and harmonization within the EU is not optional for member states. By the signing and ratification of the treaties that establish the $\mathrm{EU}$, member states delegate a part of their sovereignty to the EU-institutions and accept the binding EU-regulations and directives which can be enforced through the EU-Commission and the Court of Justice of the EU. The EU is founded on the values of respect for human dignity, liberty, democracy, equality, the rule of law and respect for human rights, including the rights of persons belonging to minorities. These values are common to the member states in a society in which pluralism, non-discrimination, tolerance, justice, solidarity and equality between women and men prevail. ${ }^{28}$

The EU-Treaty recognizes and incorporates the fundamental human rights stipulated by other international treaties and conventions, like the European Convention for the Protection of Human Rights and Fundamental Freedoms (ECHR) and the Charter of Fundamental Rights of the European Union of 7 December 2000, as adopted in Strasbourg, on 12 December 2007, which shall have the same legal value as the Treaties. ${ }^{29}$ Furthermore, in the preamble of the EU-Treaty it is said that inspiration is drawn from the cultural, religious and humanist inheritance of Europe, from which the universal values of the inviolable and inalienable rights of the human person, freedom, democracy, equality and the rule of law have developed. ${ }^{30}$

\subsection{Dematerialization of Crime}

I would like to pay a little attention to the phenomenon that the immaterial becomes more and more important. In the modern world we spend a lot of time online on the internet and there are a lot of young people who not only 'live with internet', but actually 'live on the internet'. The online world is a virtual world. Physical products and acts are increasingly replaced by virtual services and information, while

27 See for example the impact of Brexit on the EU environmental agreements in Colin T Reid, "Brexit and the Future of UK Environmental Law,"Journal of Energy \& Natural Resources Law, 34:4, (2016) : 407-415, http://dx.doi.org/ 10.1080/02646811.2016.1218133.

28 The Treaty on the European Union, Art. 2.

29 Ibid, Art. 6.

30 Ibid, Preambule. 
business transactions are progressively carried out on the basis of virtual money and in a virtual trading environment. People do not meet physically on the streets, in the cafes and public places, but by joining virtual communities and groups on the internet. This "dematerialization" 31 together with the aforementioned "deterritorialization" causes the difficulty to retrieve the objects and perpetrators of crimes. It is also not so easy to determine the "crime scene" and to find out who the perpetrator is.

In many cases, computers and computer systems communicate with each other without any human interference. The real threat is that new forms of crimes have occurred, such as hacking, dissemination of viruses, and attacks on computer systems that can only be committed through ICT and where ICT itself is the target. These new cyber-crimes can be a big threat, not only to the privacy or goods of individuals, but also to national, international and global communities and in the end to world peace. They can destabilize economies and nations. Think of what can happen when criminals or terrorists get access to and power over computer systems that are vital to (atomic) energy supply, worldwide trading and banking or defense. It is obvious that efforts must be made to design and establish international cooperation and legal systems in order to address these threats.

\section{CONCLUSION}

What I wanted to show is that global justice asks for transnational and global consensus, cooperation and solutions. We can learn from local wisdom, but the difficulty lies in formulating the right criteria for choosing the appropriate local values and philosophies that qualify for incorporation in judicial regulatory systems. The connection or association with traditional beliefs, religion or spirituality in legal structures is far from commonly accepted and often strongly opposed. In the eyes of many people, governmental and legal structures should be neutral and only be based on modern principles that are commonly accepted. It is not so long ago that in many Western European countries, government and legislation were the domain of religion. It is beyond the scope of this article to describe the horrific practices and injustice this has brought and the bloodshed that took place before the people were freed from the yoke of the reign of religion. Tradition, spirituality and religion in Western Europe are seen as a personal matter and as guidance for personal attitude, rather than the basis on which governmental and legal frameworks are built. The situation in many other countries is completely different. In many countries forces are strong to build a nation on the basis of principles and rules of traditions and religions. It is a challenge to combine old wisdoms, traditions, philosophies and believes with modern concepts of justice and fundamental rights. And it demands courage to acknowledge that in the words of former President Obama "just because something is a tradition or part of our past does not make it right".

${ }^{31}$ The term 'dematerialization of crime' is used, for instance in Benjamin Noys, Psychopatology as a Game: J.G Ballard and Conceptual Crime, in Nicol, Bran,Eugene McNulty,Patricia Pulham, eds., (Crime Culture: Figuring Criminality in Fiction and Film, Continuum Library Studies, 2011): 48. 


\section{BIBLIOGRAPHY}

\section{Books}

Borchardt, Klaus-Dieter. The ABC of European Union Law , Luxembourg: Publications Office of the European Union, 2010

Noys, Benjamin. Psychopatology as a Game: J.G Ballard and Conceptual Crime, in Nicol, Bran, Eugene McNulty, Patricia Pulham, eds. Crime Culture: Figuring Criminality in Fiction and Film, Continuum Library Studies, 2011

Russell, B. Bertrand Russell's Best. New York: Routledge Classics, 2009

\section{Journals}

Wallinga, Tammo. "The Common History of European Legal Scholarship."Erasmus Law Review 4, Issue 1 (2011): 3. http: / / www.erasmuslawreview.nl/tijdschrift/ ELR/2011/1/ELR_2210-2671_2011_004_001_002.pdf

Ruggie, John Gerard. "Territoriality and Beyond: Problematizing Modernity in International Relations."International Organization 47, No. 1 (1993): 152-154. http: / / www.rochelleterman.com/ir/sites / default/files / Ruggie\%201993.pdf

Towett, Geofrey, Peter Gutwa Oino, and Audrey Matere, eds. "The Female Genital Mutilation Act 2011 of Kenya: Challenges Facing its Implementation in Kajiado Central Sub-County, Kenya."International Journal of Innovation and Scientific Research10, No. 1 (Oct. 2014): 40-49. http://www.ijisr.issr-journals.org/issue.php?issue $=19$

Kiefer, Anna. "The Thirtieth Anniversary of the Schengen Agreement: Retrospective and Perspective in Light of the Migrant Crisis " Cornell Int'l L.J. Online, (2015) Vol. 3

http: / cornellilj.org/wp-content/uploads / 2015/12/Anna-Kiefer-The-Thirtieth-Anniversary-of-the-Schengen-Agreement-3-CILJO-22.pdf

Damman, Jens C. “The Righ to Leave the Eurozone."Texas International Law Journal 48:125, Issue 2 (2013): 126-137. http://www.tilj.org/content/journal/48/ num2/Dammann125.pdf

Reid, Colin T. "Brexit and the Future of UK Environmental Law." Journal of Energy \& Natural Resources Law, 34:4 (2016) : 407-415. http://dx.doi.org/10.1080/ 02646811.2016 .1218133 


\section{Legal Documents}

Charter of the United Nations

Constitution of Kenya. National Council for Law Reporting with the Authority of the Attorney General, Laws of Kenya: Constitution of Kenya, The Official Law Reports of the Republic of Kenya, Revised Edition 2010

International Covenant on Civil and Political Rights

Rome Statute of the International Criminal Court and Resolution RC/Res.6, http:/ / www.icc-cpi.int/iccdocs/asp_docs/Resolutions/RC-Res.6-ENG.pdf

Statute of the International Court of Justice

Treaty establishing the European Coal and Steel Community (Treaty of Paris, 1951)

Treaty establishing the European Economic Community (Treaty of Rome 1967)

Treaty on European Union (Maastricht Treaty, 1992)

Treaty of Amsterdam amending the Treaty of the European Union, the Treaties establishing the European Communities and certain related acts (Amsterdam Treaty, 1997)

Treaty of Lisbon amending the Treaty on European Union and the Treaty establishing the European Economic Community (Lisbon Treaty, 2007)

United Nations Declaration on the Rights of Indigenous Peoples, adopted by the General Assembly of the United Nations on September 17th 2007, 61/295.

\section{Internet}

Otto, Martin. Law. European History Online,2011.http://ieg-ego.eu/en/threads/ backgrounds/law

Shobhith, Seth. Why These European Countries Don't Use The Euro. Investopedia, 2016

http:/ / www.investopedia.com/articles / investing/050515/why-these-europeancountries-dont-use-euro.asp

Survival International.“The Uncontacted Indians of Brazil.” http://www.survivalinternational.org/tribes/uncontacted-brazil andinformation provided in 
http:/ / www.funai.gov.br/

United Nations Office on Drugs and Crime. "Study on the Effects of New Information Technologies on the Abuse and Exploitation of Children, Vienna-New York.” https://www.unodc.org/documents/organized-crime/cybercrime/ Study_on_the_Effects.pdf

University Twente News. "ICT Plays an Increasing Part in Criminal Activities: Perpetrators are often Young, Female, and Dutch."https://www.utwente.nl/en/ news /!/2013/3/158372/ict-plays-an-increasing-part-in-criminal-activities , https: / /www.whitehouse.gov/the-press-office/2015/07/26/remarks-president-obama-kenyan-people 